\title{
A Boa-Fé como Modelo \\ (uma aplicação da Teoria dos Modelos, de Miguel Reale $)^{1}$
}

\section{Judith Martins-Costa}

Uma coisa, pertencentea uma ordem de espinitos, éa onganizasão da vida jurídica da sociedade, e outra muito diversa, pertencente a outra ordem, éa análise ou a sintese dos elementos componentes do direito. Entre a crítica e a encamação do direito haverásempre grande distância. Assim como nema bistória, nem a teoria da arte, foi nunca obra dos grandes artistas, não são também os legisladores que fazem a sistematização dos fatos e das relações jurídicas. Joaquim Nabuco, "Um Estadista do Império").

Sumário: Introdução. I) A Teoria dos Modelos: dos modelos doutrinários aos modelos jurisprudenciais. II) A Casuística da Boa-Fé Objetiva nos Tribunais Brasileiros.

\footnotetext{
"Texto originalmente apresentado, com o título "A Boa-Fé como Modelo (notas para a compreensão da boa-fé obrigacional como modelo doutrinário e jurisprudencial no Dircito Brasileiro") ao Convegno La Formazione del Sistema Giuridico Latincamericano: Codici e Giuristi, Amalfi, abril de 2001, tendo sido atualizada apenas a teferência ao novo Código Civil Brasiletro.
} 
A boa-fé obrigacional, também dita boa-fé objetiva, chegou tarde ao Direito Brasileiro. Só muito recentemente, a partir de 1990, o direito legislado passou a contemplá-la como regra específica, e ainda assimn no domínio próprio das relações de consumo ${ }^{2}$. $O$ vigente Código Civil Brasileito, de 1916, não contém regra acezca da boa-fé obrigacional, diversamente do que ocorte com o novo Código, ora em aguardo da sanção presidencial, no qual são expressivas as referências ao princípio ${ }^{3}$. É bem verdade que o vetusto Código Comercial, de 1850 , alude, no art. 130 , à boa-fé como cânone hermenêutico dos contratos ${ }^{4}$, mas este texto jamais desempenhou funções de cláusula getal, pouco passando de letra morta ${ }^{5}$. Mesmo assim, nos últimos quinze anos, o princípio, em sua feição objetiva, impositiva de standard de conduta aos que entram em relação obrigacional, vem sendo aplicado pela jurisprudência nacional como fonte de específicos deveres de conduta e como limite ao exercício de direitos, conquanto nem sempre seja usada idêntica gramática, havendo mesmo expressivas difetenças quanto ao modo e às hipóteses de sua incidência.

\footnotetext{
${ }^{2}$ Código de Defesa do Consumidor (Lei ${ }^{\circ} 8.078$, de 11.9 .90 ) a prevê no art. $4^{\circ}$, inciso Mr, como um dos principios da Política Nacional das Relações de Consumo, visando à "barmonização dos interesses dos participantes das relą̧óes de consumo" e no art. 51 , inciso IV, como critério de aferíçäo de abusividade de cláusula contratual, cujo efeito é a nulidade.

"Pata as referencias ao novo Código Civil, vide o texto O novo Código Civil Brasileiro: em busca da "ética da situação", ora nesta obra e ainda MORRIRA ALVES, José Carlos, "A Boa-Fé Objetiva no Sistema Contratual Brasileiro", Revista Roma e América Roma, vo. 7,1999.

${ }^{4}$ Art. 130, caput e inciso l, in verbis: "Sendo necessário interpretar as cláusulas do contrato, a interpretação, além das regras sobreditas, será regulada sobre as seguintes bases: 1. a inteligência simples e adequada, que for mais conforme à boa-fé, e ao verdadeiro espírito e natureza do contrato, deverá sempre prevalecer à rigorosa e restrita significação das palauras".

${ }^{5}$ Acentua, a propósito, Josć Carlos MOREXRA ALVES: "É de notar-se, porém, que esse dispositivo, que se apresenta com a natureza de cláusula geral, até época relativamente recente foi tido como simples princípio de bermenêutica que se baseia na boafé subjetiva". (in "ÂA Boa-Fé Objetiva no Sistema Conttatual Brasileiro", cit., p. 194).
} 
Pesquisa realizada em sites de Tribunais brasileiros ${ }^{6}$ indica que no ementário de decisões do Superior Tribunal de Justiça - ao qual compete, constitucionalmente, unificar a jurisprudência nacional ${ }^{7}$ - dezoito (18) decisões encontram fundamento no princípio ${ }^{8}$. No Supremo Tribunal Federal, o guardião da Constituição Federal, embora sejam inúmeras as decisões fundadas na boa-fé possessótia e na proteção aos tetceiros de boa-fé, há um único acórdão que revela a função da boa-fé como regra de conduta, aí sendo o princípio alegado, no Direito Administrativo, como limite à defesa, em juizo, da Administração Pública ${ }^{9}$. No âmbito dos Tribunais de Justiça dos Estados é o Tribunal de Justiça do Rio Grande do Sul, pioneiro na sua aplicação, que apresenta o maior número de decisões fundadas na boa-fé objeriva, havendo mais de trezentas ( 300 ) referências, das quais aproximadamente vinte e cinco por cento $(25 \%)$ apresentam uma feição inovadora, da qual é possivel retirar uma verdadeira construção das funções que, tal qual observa-se no Direito Comparado,

"Pesquisa realizada nos meses de março a junho de 2001, pela Internet, tendo em conta os seguintes critérios: Tribunais Superores (STF e STJ) e Tribunais de Justiça dos Estados do Rio Grande do Sul (304 acórdàos), Rio Grande do Norte (9 acórdãos) Pará (9 acórdãos) Bahia (2 acórdãos), Goiás (6 acórdãos), Paraná (1 acórdão), Paraíba (1 acórdão), Rondônia(1 acórdāo), Permambuco (9 acórdãos) e Distrito Federal (24 acórdãos). Os demais Tribunais estaduais ou não têm nenhuma referência en seus ementários, ou não têm a jurisprudència acessivel em suas bome pages. Foram feitas consultas por e-mail junto aos Tribunais de Justiça de São Paulo, Rio de Janeiro, Pernambuco, Mato Grosso e Espírito Santo, as quais nāo tiveram resposta, salvo a procedida junto ao Tribunal de Justiça de Pernambuco. A Justiça estadual de São Paulo, através do Juizados Especiais Cíveis, conquanto não tenha jurisprudência disponibilizada pela Internet, está começando a utilizar o principio como "nandamento de recíproca confrança incumbente às partes" notadamente em tema de Direito do Consumidor, como exemplificativamente, os acórdảos proferidos pelo seu Primeiro Colégio Recursal dos Juizados Especiais Cíveis da Capital nos Recursos $n^{\circ}$ os 7.959 (j. em 14.12.2000); 7.766 (j. em 13.11.2000); 7747 (j. em 1․ 11. 2000 e 7.767(j. em 13.11.2000), em todos eles sendo Relator o Juiz Laerte MARRONE. Para a realização desta pesquisa os verbetes procurados foram: "boa lé objetiva"; "boa-fé e obrigação"; "boa-fé contratual", "boa-fé e contrato" e "boa-fé e princípio". Foram desconsiderados os acórdāos relacionados às palavras-chave "boa-fé e contratos" rełativos à proteção da boa-fé de texceiros que diziam respeito a situações subjetivadas da boa-fé. Assinala-se que, segundo os sistemas de indexaçāo usuais, as expressöes buscadas deveriam constax da ementa. Para esta pesquisa devo registrar o meu agxadecimento ao valioso auxílio prestado pelo académico de Direito Alexandre PERETRA DUTRA, da Faculdade de Direito da UFRGS, que desenvolve projeto de iniciação científica sob minha orientação, com bolsa de estudos patrocinada pelo CNPq.BYPIC.]

${ }^{7}$ Constituição Federal, art. 105, inciso III, ao conferir a competência para julgar, em recurso especial (Resp), "as causas decididas, em única ou última instância, pelos Tribunais Regionais Federais ou pelos Tribunais dos Estados, do Distrito Federal e Territórios", quando a decisão recorrida: a) contrariar tratado ou lef federal, ou negar-lhes vigência; b) julgar válida let ou ato de governo local contestado em face de lei federal; c) der à lei federal interpretação divergente da que the haja atribuido outro tribunal.

${ }^{8}$ Nomeadamente: Agr. Reg. no Al n" 47. 901 - 3 - SP;AGA 47901;EDRESP 167691;RESP 256274;RESP 107211;RESP 80036; RESP 32890;RESP 3714/RS;RESP 7187/SP; RESP 85521/PR; RESP 101061/PB; RESP 157841/SP; RESP 5932/RS; RESP 158728/Rj; RESP 18.4573/SP, RESP 95535/SP;REMS n 6183MG;.ROMS 6183; ROMS 1694/RS.

${ }^{9}$ STF, 2a T, RE 158448/MG, Relator Mituistro Marco Aurélio de MELLO, j. em 29.06.1998, sendo a boa-fé invocada articuladamente aos princípios da continuidade da prestaçăo de serviços e da realidade. 
notadamente o direito alemão e o italiano, têm sido cometidas ao princípio ${ }^{\text {st? }}$.

Ora, os dados desta pesquisa sinalizam uma "modelagem brasileira" da boa-fé objetiva, de cunho fortemente jurisprudencial.

Numa cultura jurídica na qual é ainda forte a tradição legalista, ao apego à lei em seu aspecto formal, à sua mais espessa literalidade, uma tal circunstância é curiosa. Na busca das razões que a expliquem, recotro preliminarmente (Parte I) a um especifico recorte teórico, qual seja, o da teoria das fontes e dos modelos jurídicos, proposta por Miguel Reale $^{11}$.Compreendido este aporte teórico - que é aqui suporte, e busca de explicação tentarei visualizar a formação de um modelo jurisprudenial da boa-fé objetiva no Direito Brasileiro, mediante a indicação das funções que, na concreta prática da vida jurídica, é o mesmo chamado a operar (Parte II).

\section{I) A TEORIA DOS MODELOS: DOS MODELOS DOUTRINÁRIOS AOS MODELOS JURISPRUDENCIAIS.}

Ao debruçar-se sobre o fenômeno da normatividade, percebeu Miguel Reale que as normas jurídicas, provindas das quatro fontes às quais são reconhecidos os atributos da autoridade e da prescritividade - a saber, a fonte legislariva, a jurisprudencial, a consuerudinária e a negocial - podem apresenrarse como modelos, vale dizer, como "estruturas normativas que ordenam fatos segundo valores, numa qualificação tipológica de comportamentos futuros, a que seligam determinadas conseqüências"12. Correspondentes, no plano jurídico, às estruturas normativas verificadas nas estruturas sociais, os modelos são constantemente construídos pela experiência jurídica, distinguindo-se entre modelos jurídicos - assim os provenientes das quatro fontes de produção jurídica, dotados que são de força prescritiva - e os modelos dogmáticos, ou hermenêuticos, cuja elaboração é doutrinária e cuja força é indicativa, argumentativa ou persuasiva.

\footnotetext{
${ }^{10}$ Para este cômputo a autora considerou as invocaçōes a boa-fé não repetitivas e as decisōes nas quais as funçōes da boa-fé objetiva são efetivamente desenvolvidas, desconsiderando aquelas em que o princípio é meramente alegado, sem a correspondente motivação e o estabelecimento dos nexos com a concreta situação fática e ainda os acórdăos fundados em similar situação de fato e idêntica argumentação.

"Veja se, de Miguel REALE, "Fontes e Modelos no Direito - para um novo paradigma hermenêutico", São Paulo, Saraiva, 1994, e, "Para uma teoria dos modelos juxídicos", in "Estudos de Filosofia e de Ciência do Direito", São Paulo, Saxaiva, 1978.

2 REALE, Miguel, "Para uma teoria dos modelos juridicos", in "Estudos de Flosofía e de Ciência do Direito", cit., p. 17.
} 
A referência à força meramente indicativa ou persuasiva da doutrina merece, no Direito Brasileiro, um cuidado particular. Somos, os luso-brasileiros, tributários de uma longa tradição "bartolista"t3, e, portanto, a força da doutrina tem um peso específico, de alta densidade cultural. É que, desde as nossas mais fundas origens, o mos italicus, refletido exemplarmente na obra de Bartolo de Saxoferrato, conformou uma mentalidade. Se razão cabe a Fernand Braudel ao aludir à "longa permanência" das estruturas na História ${ }^{14}$ - comparativamente às conjunturas e aos eventos, conformadores de ciclos de média e de curta duração - o certo é que a estrutura das mentalidades, dos "enquadramentos mentais" a que alude Braudel ${ }^{15}$ é a que apresenta a mais longa duração. É o que ocorre com a nossa visão do papel da doutrina na formação do Direito.

No antigo direito lusitano nem o centralismo jurídico representado pela precoce ordenação do Direito sob o signo da autoridade estatal - nossas primeiras Ordenações do Reino são de $1447^{16}$, - teve força para afastar a doutrina como verdadeira fonte de direito.

${ }^{13}$ Veja-se ALMEIDA COSTA, Mario Júlio, "Romanismo e Bartolismo no Direito Português", Boletin da Faculdade de Direito da Universidade de Coimbra vol. XXXVI, 1960, p. 16.

14 BRAUDEL, Fernand, "História e Ciências Sociais", tradução portuguesa de Rui Nazaré, Lisboa, Editorial Presença, $4^{a}$ edição, 1982, notadamente o ensato "A Longa Duração", p. 7 a 39. Para a apreensão das categorias braudelianas na História do Direito, PARADISI, Bruno, "Questioni Fondamentali per una Moderna Storia del Diritto", in Quaderni Fiorentini per la Storia del Pensiero Giuridico Modemo, vol. 1, Firenze, 1972, em especial pp. 31 e ss., e VARELA, Laura Beck, 'Mlgumas Contribuições da Ciência Histórica à Tarefa do Historiador do Direito", in Revista da Faculdade de Direito da Universidade Federal do Rio Grande do Sul, vol. 18, Porto Alegre, 2000.

15 BRAUDEL, Fernand, "História e Ciências Sociais, cit., p. 14.

to Ordenações Afonsinas cuja conclusão ocorreu no segundo semestre de 1446 ou no primeiro de 1447. O seu sistema de fontes estabeleceu (Livro II, título $\mathrm{IX}$ ) a hierarquia entre as leis do reino que, se iasuficientes seriam supridas "pelas Leys Imperiaies, e pelos Santos Canones", e sucessivamente "se o caso de que se trauta em partica, nom fosse determinado per Ley do Regno, ou estilo, ou custume suso dito ou Leyx Imperiaaes, ou Santos Canones, entom mandamos que se guardem as grosas d"Acursio encorporadas nas ditas Leys. E quando pelas ditas grosas o caso non for determinado, mandamos, que se guarde a opiniom de Bartholo, nó embargante, que os outros Doutores diguam o contrario". O sistema foi mantido, com pequenas variantes, nas Orủenações Manuelinas (redação definitiva em 1521) e nas Ordenaçōes Filipinas (1603, que vigoraram no Brasil atê 1916). 
Ainda que os textos legislativos previssem, formalmente, o caráter de fonte subsidiária, relatam os historiadores do ius commune ibérico ter por vezes cabido à doutrina de Acursio e Bartolo papel proeminente frente ao próprio direito do rei ${ }^{i 7}$.

Isto significa dizer que em nossa profunda mentalidade, paradoxalmente, ${ }^{18}$ articulouse, ao legalismo, a atenção à doutrina como fonte de produção de modelos hermenêuticos, mesmo os derivados da experiência estrangeira. Para os efeitos de uma possivel história das mentalidades jurídicas, o termo "bartolismo" indica, pois, este fenômeno cultural, marca petrnanente, o de em nossa forma mentis estar fortemente arraigada a idéia de a doutrina não apenas desenvolver o papel de formadora dos cânones de interpretação, mas o de, concebendo "os modelos bermenêuticos destinados a preencher as lacunas do sistema" tornat-se fonte prescritiva. Diferentemente do que ocorre em outros páses, entre nós os juízes tecorrem, em suas decisões, a largas citações da doutrina, nacional ou estrangeira. Por esta via, os modelos doutrinários, largamente aceitos pela jurisprudência, são convertidos em modelos jurídicos jurisprudenciais, estes sim marcadamente prescritivos, "graças ao poder constitucionalmente conferido ao juiz ${ }^{200}$, assim dinamizando de maneira exponencial (ou, por vezes, cristalizando), as soluções oferecidas pela fonte legisłativa, em si mesma estática.

Os modelos jurisprudenciais incluem-se entre os modelos jurídicos ou prescritivos. Estes, diz Reale, não são o mesmo que normas, constituindo suas especificações, geralmente resultando de uma pluralidade de normas que, entre si articuladas numa certa estrutura, compõen uma unidade lógica de sentido"2t. Se determinada estrutura serve de base "a uma série ordenada e conjugada de atos tendentes a alcançar certos objetivos visados", tem-se um modelo, que assim se apresenta como uma "estrutura paradigmática" a qual, no campo das ciências sociais, notadamente no Direito, é matcada por um essencial dinamismo, sendo-lhe

\footnotetext{
${ }^{17}$ Alirma HESPANHA que em Portugal "apesar de as Ordenações conferirem ao direito romano um lugar apenas subsidiário no quadro das fontes do Direito (Ordenaçóes Filipinas, 111,64 ) na prática ele era o direito principal, sendo mesmo aplicado contra o preceito expresso do direito local" (HESPANHA, Antonio Manuel, "Panorama da Cultura Juridica Européia" Lisboa, Publicaçōes Europa-America, 1997, p. 67, nota 79, por "direito romano" devendo entender-se fundamentalmente a obra de Acursio e Bartolo).

${ }^{18}$ O paradoxo diminuirá se consideramos que a doutrina brasileira verr recoberta, em larga medida, pela tradição praxista, a qual é pouco criativa, pois cingida aos comentários da prática forense, caracterizandose, por vezes, por uma vocação de retrospectividade mais do que de prospectividade.

"REALE, Miguel, "Fontes e Modelos no Direito - para un novo paradigma hermenêtitico", cit, p. 107.

20 Idem, ibidem.

${ }^{21}$ REALE, Miguel, "Fontes e Modelos do Direito - para um novo paradigma hermenêtico", cit., pP. 29 e 30 .
} 
inerente "o movimento, a direção no sentido de um ou mais fins a serem solidariamente alcançados ${ }^{\text {'mz }}$. Um modelo pode, assim, articular normas de hierarquia diversa, compondo, numa unidade de sentido, princípios constitucionais, regras infraconstitucionais e prescrições que resultam da atividade jurisdicional. Por isto é que, enquanto expressivas de modelos, as normas "passam a ser captadas (...) em sua plenitude só quando o intérprete atende à dinamicidade que lhesé inerente e à totalidade dosfatores que atuam em sua aplicą̧ão ou eficácia, ao longo de todo o tempo de sua vigência ${ }^{\text {nz:3. }}$.

Bem por isto, não são os modelos estruturas estáticas ou fixas, presas ao passado: sendo elaborados continuamente têm, a par da vocação retrospectiva (por decorrerem das fontes, que são estáticas) a vocação prospectiva, pois se projetam no presente e para o futuro, assim agregando a experiência do passado, mas estando abertos para o que está por vir, nesra perspectiva possibilitando a solução de novos problemas ou a adequação das soluções tradicionais às novas escalas axiológicas vigentes ${ }^{24}$.

Ora, no Direito Brasileiro a boa-fé objetiva apresentou-se, inicialmente, como um modelo hermenêutico, ou doutrinário, na acepção que lhe dá Miguel Reale, podendo ser atribuída à obra de Clóvis do Couto e Silva ${ }^{25}$, eminente jurista falecido em 1992, Professor Titular da Faculdade de Direito do Rio Grande do Sul, a sua

\footnotetext{
2.7 REALE, Miguel, "Jurisprudência e Doutrina", in "Questôes de Direito", São Paulo, Sugestões Literárias, 1981.

${ }^{2.3}$ REALI, Miguel, Fontes e Modelos ,cit, p. 30, grifos do autor.

${ }^{24}$ Creio que a percepção de Reale acerca da prospectividade dos modelos plasina a antecipação, em décadas, do pensamento que, na Europa, viria a ser desenvolvido por adeptos mais recentes da Teoria Hermenêutica, como Giuseppe ZACCARIA acerca da positivação das normas como un processo dinàmico - e não por acaso estruturado numa triade - ou por Friederich MÜLAER sobre a normatividade como "processo estruturado", conseqüente à distinção que procede entre o texto da norma e o seu "programa" como "pauta ordenadora" obtida no processo de interpretação, o sentido e - alcance da norma sendo alcançados apenas na concretizaçăo (para estas referências vide ZACCARiA, Gjuseppe, "Sul concetto di positività nel diritto",in Diritto Positivo e Positività del Diritto, Turim, Giappichelli, 1991, e L'Arte dellintetpretazione, Pádua, Cedam,1990 e MÜLLER, Friedrich, "Discouts de la Méthode juridique", Paris, PUF, 1996, en especial pp. 186 e ss.)

${ }^{25}$ Notadamente em "A Obrigação como Processo", Tese de Cátedra, Porto Alegre, 1964, postexiormente publicada (São Paulo, José Bưshatsy Editor, 1976) e em "O Princípio da Boa-Fé no Direito Brasileiro e Portugués", in "Estudos de Direito Civil Brasileiro e Português", São Paulo, Revista dos Tribunais, 1986, p. $43-72$.
} 
efetiva confotmação como princípio ativo, capaz de operar "verdadeira transformação jurídica através da doutrina e do Poder Judiciário ${ }^{26}$ ". Conquanto referência à boa-fé contratual já constasse das obras de Miguel Maria de Serpa Lopes ${ }^{27}$, Orlando Gomes ${ }^{28}$ e de Alípio Silveira ${ }^{29}$, as decisões que iniciaram a trajetória de seu acolhimento como modelo jurisprudencial fazem expressas referências à obra de Couto e Silva e a de autores que divulgou, como o português Mario Júlio de Almeida Costa, ${ }^{30}$ os quais deram ao princípio um desenvolvimento dogmático ausente das demais obras mencionadas, explicitando os deveres de cooperação que, na relação obrigacional, decorrem da sua incidência. Como observa Couto e Silva, "os autores que escreveram, posteriormente ao CC brasileiro, não mencionam em geral a importância do princípio da boa-fé para uma moderna concep̧̧ão da relação obrigacional, não a definem como uma complexidade, uma estrutura ou um sistema de

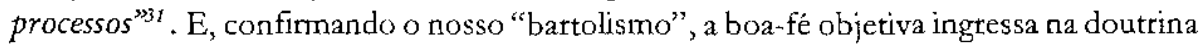
brasileira pelas mãos de Emilio Betti, como alude Couto e Silva ao lembrar o 'magnífico curso"proferido pelo extraordinário jurista italiano na Faculdade de Direito da Universidade Federal do Rio Grande do Sul, em $1958^{32}$.

Com base na percepção da relação obrigacional como um processo que se desenvolve no tempo, en sucessivas fases, polarizado pelo adimplemento, transpôs Couto e Silva para o direito civil brasileiro a concepção bettiana da existência imanente, nesras relações, de deveres de colaboração, ora secundários ou anexos à obrigação ptincipal, ora apresentando-se, por força da boa-fé, como deveres autônomos. Conjugando esta concepções aos aportes da doutrina e da jurisprudência alemãs, que

${ }^{26}$ COUTO E SIl_VA, Clóvis, "O Princípio da Boa-Fé no Direito Brasilciro e Portuguêes", cit., p. 43.

${ }^{27}$ SERPA LOPES, Miguel Maxia. "Curso de Direito Civil", Rio de Janeiro, Freitas Bastos, 1" edição, 1957.

${ }^{28}$ GOMES, Orlando, "Transformaçôes Gerais do Direito das Obrigaçōes", São Paulo, Revista dos Tribunais, $1^{2}$ edição de 1967.

${ }^{29}$ SILVEIRA, Alípio, "A Boa-Fé no Código Civil", Tomos I e II, São Paulo, Editora Universitária de Direito, 1973. Este, autor de um amplo estudo que procura distinguir entre a "boa-fé crença" e a "boa-fé lealdade", mesmo assim atribui, à segunda, o caráter de un estado subjetivado, como se observa pelos grupos de casos que analisa no $2^{\circ}$ volume de sua obra.

${ }^{30}$ ALMEIDA COSTA, Maxio Júlio, "Direito das Obrigaçöes", Almendina, Coimbra, ora na $8^{2}$ edição (2000), e cuja primeira ediçào é de 1968.

" COUTO E SILVA, Clóvis, "O Princípio da Boa-Fé no Direito Brasileiro e Português", cit., p. 58.

${ }^{32}$ COUTO E SILVA, Clóvis, "O Princípio da Boa-Fé no Direito Brasileiro e Poruguês", cit., p. 43, nota 1. 
deram um notável desenvolvimento à norma do parágrafo 242 do $B G B$, atrilbuiu Couto e Silva, à boa-fé objetiva, o papel de fonte autônoma de direitos e obrigações, por cuja incidência "transforma-se a relą̧ão obrigacional manifestando-se no vinculo dialético e polêmico, estabelecido entre devedor e credor, elementos cooperativos necessários ao correto adimplemento ${ }^{333}$.

Enfatizou Couto e Silva que o fato de o Código Civil não contemplar de forma expressa o princípio - constatação que decorreria de uma interpretação "meramente gramatical", consagradora de "um absurdo ${ }^{\text {vg4 }}$ - não poderia levar à conclusão de que o mesmo não integra o ordenamento. "Quando num código não se abre espaço para um princípio fundamental, como se fez como princípio da boa-fé, para que seja enunciado com a extensão que se pretende" afinnou, "ocorre ainda assima sua aplicaçâo por ser o resultado de necessidadeséticas essenciais, que se impõem ainda quando falte disposição legislativa expressa", reconhecendo, porém, que, neste caso, 'a percepção ou captação de sua ap licação torna-se muito dificil, por não existir uma lei de referencia a que possam os juizes relacionar a sua decisão $0^{35}$.

Estas dificuldades foram e continuam a ser sentidas. No entanto, progressivamente, a partí da década de 80 , parte da jurisprudência passa a acolher esta doutrina, concretizando o princípio e formando, em pequenos passos, a sua dogmática.

A jurisdição, acentua Reale, "é antes de mais nada, um poder constitucional de explicitar normas jurídicas, e, entre elas, modelos jurídicos"36. Este poder, embora desenvolvido normalmente na "realização das normas legais adequadamente aos casos concretos ${ }^{37}$ também se apresenta, excepcionalmente, como "poder de editar criadoramente regras de direito, em bavendo lacuna no ordenamento" 3 .

A inexistência de expressa previsão no Código Civil ao princípio da boafé passou a exprimir lacuna, angustiosamente sentida quando os tradicionais princípios de Direito das Obrigações - o da autonomia privada, expresso na auto-vinculação, e o da responsabilidade por culpa - começaram a se mostrar mais que nunca insuficientes para uma justa solução de casos resultantes, por exemplo,

${ }^{33}$ COUTO E SILVA, Clóvis, "O Princípio da Boa-Fé no Direito Brasileiro e Português", cit., p. 47.

${ }^{34}$ As expressōes grifadas estão em COUTO E SILVA, Clóvis, "O Princípio da Boa-Fé no Direito Brasileiro e Portuguêe", cit., p. 61.

${ }^{35}$ COUTO E SILVA, Clóvis, "O Princípto da Boa-Fé no Direito Brasileiro e Português", cit., p"p. 61 e 62.

${ }^{36}$ REALE, Miguel," Fontes e Modelos do Direito", cit., p. 69.

${ }^{37}$ Idem, P. 70.

38. Ydem, ibidem. 
da contratação por adesão, ou do exercício abusivo de posição contratual, ou do indevido recesso das tratativas contratuais, ou da necessidade de revisão das bases contratuais em casos de excessiva onerosidade, entre outros tantos que poderiam ser aqui lembrados. Aí está a razão pela qual o princípio da boa-fé - que, bem lembrava Couto e Silva, "endereça-se sobretudo ao juiz e o instiga a formar instituiçôes para responder aos novos fatos " ${ }^{3 / 39}$ passou a conformar verdadeiro e próprio modelo jurisprudencial.

E constitui modelo a boa-fé porque, para a sua correta aplicação, não pode o juiz prescindir da articulação, coordenada, de outras normas integrantes do ordenamento, compondo-as numa unidade lógica de sentido. É preciso recorrer, exemplificativamente, às regras da mora, ou da resolução contratual, ou da responsabilidade civil, ou do adimplemento, ou a tópicos integrantes do direito legislado, como o da "utilidade da prestação" para o $\operatorname{credor}^{43}$, ou a que consagra o poder do juiz de reduzir a cláusula penal ${ }^{41}$, ou às regras da exceção de contrato não cumprido ${ }^{42} \mathrm{e}$ ainda as do abuso de Direito ${ }^{43}$, ou a outros princípios ou direrrizes, expressos ou implícitos no ordenamento, como o da moralidade e razoabilidade ou a solidariedade social, ou, enfim, aos cânones de interpretação e integração do contrato, para lograr uma adequada concreção do princípio - adequada porque viabilizadora da inserção, no ordenamento, da nova solução alcançada por via jurisprudencial, e porque afastada do puro e simples voluntarismo judicial.

Para saber como vêm os juizes brasileiros implementando este modelo, essencial é o exame casuístico das funções que the estão sendo concretamente cometidas. É do que agota me ocuparei, tendo em conta a jurisprudência do Superiot Tribunal de Justiça e do Tribunal de Justiça do Rio Grande do Sul.

\section{II) A CASUÍSTICA DA BOA-FÉ OBJETIVA NOS TRIBUNAIS BRASILEIROS}

Se o sentido geral da boa-fé é o de norteat o teor geral da colaboração intersubjetiva, especialmente no Direito das Obrigações, é porque a boa-fé produz deveres instrumentais e "a v o l u n t a r í s t a s"44, neologismo que emprego para indicar que não derivam necessariamente do exercício da autonomia privada nem de punctual explicitação legislativa: sua fonte reside justamente no princípio,

\footnotetext{
39 COUTO E SLLVA, Clóvis. "O Princípio da Boa-Fé no Direito Brasileiro e Português", cit, p.53.

4) Código Civil, art. 956, parágrafo único.

4! Código Civil, art. 924.

${ }^{42}$ Código Civil, art. 1092, caput.

${ }^{43}$ Código Civil, axt. 160, inciso 1, a contrario.

${ }^{44}$ Assim o meu "A Boa-Fé no Direito Privado", São Paulo, Revista dos Tribunais, 1999, p. 438.
} 
incidindo em relação a ambos os participantes da relação obrigaciona $\mathrm{I}^{45}$.

O efetivo desenho destas hipóteses deve ser recortado da jurisprudência que vem empregando o método de raciocínio tópico para modelar "grupos de casos típicos" de violação do dever de agir segundo a boa-fé, em construção ainda não-sistemática, das hipóteses ${ }^{46}$, porérn indicativa das figuras componentes de um possível código discursivo da boa-fé em efetivo uso em alguns Tribunais brasileitos.

A firn de sistematizar estes casos, proponho agrupá-los em três setores, o primeiro deles atinente ao que chamarei de "função de otimização do comportamento contratual" , o segundo relativo à "função de reequilibrio" do contrato e o tercciro correspondente à "função de limite" no exercício de direitos subjetivos, recolhendo casos que dizem respeito às relações privadas de direito comum, de direito do consumidor e de direito administrativo, campo de também especial relevância na atuação da boa-fé objetiva.

\section{A) A BOA-FÉ E A FUNÇÃO DE OTIMIZAÇÃO DO COMPORTAMENTO CONTRATUAL}

A função otimizadora do comportamento contratual é obtida por dois modos diversos: de um lado, pela imposição de deveres de cooperação e de proteção dos recíprocos interesses, deveres instrumentais de conduta, pois visam o exato processamento da relação obrigacional, a satisfação dos interesses globais envolvidos, auxiliando na realização positiva do fim contratual e na proteção à pessoa e aos bens da contraparte ${ }^{4 ?}$. De outro, pela utilização do princípio da boa-fé como cânone de interpretação e integração do contrato consoante à função econômicosocial que concretamente é chamado a realizar.

\footnotetext{
${ }_{45}$ Para a explicitação deste tema, ver o meu "A Boa Fé no Direito Ptivado", cit., em especial pp. 437 e ss. ${ }^{46}$ E natural a formação tópica ou casuística quando se trata de dar concreção aos modelos jurídicos semanticamente abertos, como o de boa-fé, ocorrendo a ressistematização das decisões mediante a formação de "grupos de casos típicos" conforme o interesse concretamente lesado e consoante a identidade ou a similitude da ratio decidendi, em torno destes construindo a jurisprudência certos tópicos ou parâmetros que possam atuar, pela pesquisa do precedente, como annarras à excessiła futuação do entendimento jurisprudencial. Facilitada, assim, estará a pesquisa do precedente e a elaboração, progressiva e aberta de tópicos, nos sentido viehweguiano, obtendo-se, pouco a pouco, a ressistematização das fattispecies já previstas e permitindo-se a incorporação de novas hipóteses sem que fosse necessáxio recorrer à punctual intervenção do legislador. (Para o exame das funçôes e modos de operar as clátısulas gerais, o meu "A Boa Fé no Direito Privado", cit., 330 a 377).

4? Sobre os deveres instrumentais vide o meu "A Boa-Fé no Direito Privado", cit., p. 440.
} 
O mais imediato dever decorrente da boa-fé éo dever de lealdade com a contraparte. Já decidiu a jurisprudência ${ }^{48}$ ferir a boa-fé objetiva o comportamento de cliente de banco, titular de conta-corrente que, depois de sucessivos saques, a limite coberto ou não, alega a inexistência de débito. Assim também detectou-se a quebra do dever de lealdade de contratante de seguro privado de saúde que não preenchera, com lealdade e honestidade, o questionário sobre doenças pré-existentes, que lhe fora fornecido pela seguradora no período antecedente à conclusão do negócio jurídico, estando ciente da existência de moléstia ${ }^{49}$.

A atuação contratual dos profissionais liberais, como a dos médicos e dos advogados, caracteriza relação fiduciária, na qual os deveres de agir segundo a boa-fé não são "anexos", mas absolutamente nucleares, a fidúcia integrando o conteúdo do próprio dever principal. Por isto, já decidiu o Judiciário que "o advogado que recomenda providência judicial onerosa para o cliente e benéfica a ele, estipulando-a no contrato de bonorários, age com deslealdade, violando o princípio da boa-fé contratual', o que, na espécie, conduziu à nulidade do ajuste ${ }^{50}$.

A lealdade marca também as relações de Direito Administrativo. Em paradigmática decisão, o Superior Tribunal de Justiça assentou que "o compromisso público assumido pelo Ministro da Fazenda, através de Memorando de Entendimento, para suspensão da execução judicial de dívida bancária de devedor que se apresentasse para acerto de contas, gera no mutuário a justa expectativa de que essa suspensão ocorrerá, preencbida a condição". Daí decorrer o direiro do particular de "obter a suspensão fundado no princípio da boa-fé objetiva, que privilegia o respeito à lealdade ${ }^{251}$. A violação da lealdade restou evidente na medida da presunção que o compromisso público assumido pelo Governo, através do seu Ministro da Fazenda, o condutor da política financeira do país, e com a assistência dos estabelecimentos de crédito diretamente envolvidos, tivesse sido celebrado para ser efetivamente cumprido. Por isto a invocação, no aresto, do princípio geral da boa-fé que, se vale no Direito Privado, "vale ainda mais para a administração pública

${ }^{48}$ TJRGS, Ap. Civ. $n^{\circ} 598225720-17^{\circ}$ C. Civ. j. 06.4.99, Rel. Demétrio Xavier LOPES NETO ${ }^{49}$ TJRGS, Ap. Civ. ${ }^{\circ} 597019439-6^{*}$ C. Civ, i. 12.11.97, Antonio Janyr DALL'AGNOL JUNIOR. TJRGS, Ap. Civ.194.045.472 - $9^{2}$ C. Civ., j.26.4.94, Rel. Des. Antônio Guilherme Tanger JARDMM, in Revista Direito do Consumidor, vol. 14, P, 173.

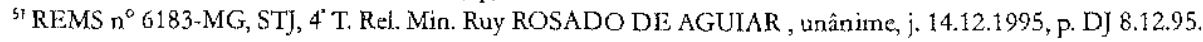
Tratava-se de hipótese en Banco do Brasil, que é entidade bancária oficial, vinculada à Administração Pública, havia ajuizado processos de execuçăo de divida contra clientes inadimplentes. O Ministro da Fazenda, autoridade à qual, em úlima instância está a autarquia bancária vinculada, havia firmado "Memorando de Entendimento" no curso de tratativas visando solucionar a questāo, que atingia um gxande número de devedores, comprometendo-se a suspender temporariamente a execução se os devedores se apresentassem para renegociar o débito. Embota o compromisso, o Banco do Brasil prosseguiu, mesmo assim, a execução judicial, regando o caráter obrigacional do mencionado "Memorando de Entenđimento". 
e para a direção das empresas cujo capital é predominantemente público, nas suas relações com os cidadãos", sendo "inconcebível que um Estado democrático, que aspire a realizar a Justiça, esteja fundado no princípio de que o compromisso público assumido pelos seus governantes não tem valor, não tem significado, não tem eficácia. Especialmente quando a Constituição da República consagra o princípio da moralidade administrativa "'s22.

Reforçando o dever de lealdade nas relações de direito administrativo - mas já agora o dever de lealdade de servidor para com a Administração Pública - está o caso em que médica, servidora municipal, foi licenciada para tratamento de saúde. No período da licença, porém, passou a atender pacientes em clínica particular, o que motivou a sua punição (suspensão disciplinar). Inconformada, a médica ajuizou ação indenizatória contra a Administração, decidindo o Judiciário pela improcedência da demanda, face ao dever, descumprido pela médica, de não atender paciente particular, ou trabalhar em instituição hospiralar particular, no perído da licença, comprometendo a plena recuperação de sua saúde, objetivo precípuo da licença que lhe havia sido concedid $a^{53}$.

Como mandamento de cooperação intersubjectiva e de consideração aos interesses do parceiro contratual a boa-fé provoca um aumento dos deveres, isto é, a sua "otimização", como demonstra decisão que impôs à companhia seguradora o dever de, previamente à suspensão dos efeitos de contrato de seguro, por inadimplemento do devedor, notificar o segurado, especificando os efeitos do não-atendimento ${ }^{54}$. Este acórdão aponta, exemplarmente, à concreção que deve presidir a aplicação da boa-fé como mandamento de consideração, pois o relativo "peso" dos deveres ata-se, de modo incindível, à natureza do contrato e às concretas circunstâncias no qual é concluído e desenvolvido. Dada a natureza essencial do seguro-saúde, a sua intrínseca importância relativamente a um bem fundamental, como o é a saúde, à extremada massificação destas prestações e a gravidade das consequuências, para o segurado, penalizado com a pexda da indenização, foi acrescido o dever de informação que, em outras circunstâncias, eventualmente não se manifestaria, assim demonstrando o acórdão o traço essencial da "circunstancialidade" que preside a incidência da boa-fé objetiva.

No mesmo sentido de otimização do conteúdo contratual pela imposição de deveres de consideração para com o parceiro contratual está acórdão que examinou hipótese de inadimplemento contratual, caracterizado pela violação do dever de abstenção de condutas que pudessem prejudicar o co-contratante, afrontados que foram, pelo contratado, os legítimos interesses daquele. Na hipótese, valendo-se da licença para uso de marca comercial, a empresa contratada, a par de não executar corretamente as obrigações principais decorrentes do contrato, passou a veicular, na Internet, propaganda comercial na qual utilizava, no mundo virtual, o "nome de dominio" da empresa conrratante, assim prejudicando, no mundo real,

\footnotetext{
52 Conforme os fundamentos da decisão citada.

${ }^{53}$ TJRGS, Ap. Civ. n" $596131060,3^{a} \mathrm{C}$. Civ. 1. 26.07.97, Rel. Des. Moacyr ADIERS.

${ }^{54}$ TJRGS, Ap. Civ. $\pi^{\circ}$ 598037257, 5 C. Civ. Rel. Des. Carlos Alberto BENKE, j. 19.03.98.
} 
os seus legítimos interesses econômicos ${ }^{55}$.

Por isto é que, tendo presente o mandamento de consideração, tem a jurisprudência atentado aos deveres de ptoteção com a pessoa e o patrimônio da contraparte. Acórdão exemplar neste sentido encontra-se na jurisprudência do STJ, pelo qual, "o estabelecimento bancário que põe à disposição dos seus clientes uma área para estacionamento de veículos assume o dever, derivado da boa-fé objetiva, de proteger os bens e a pessoa do usuário"56.

Ao apreciar a lide, não teve em conta o julgador apenas os deveres principais, decorrentes do contrato bancário, mas a totalidade dos interesses envolvidos. A proteção dos bens e da pessoa do usuário (consumidor) dos serviços bancários encontra-se finalisticamente vinculada à telação de consumo dos serviços bancários que liga o Banco e os usuátios dos seus serviços. Não estando orientados diretamente ao cumprimento da prestação principal, estes deveres estão referidos à otimização da relação obrigacional visualizada complessivamente, isto é, à satisfação dos interesses globais envolvidos.

Do mesmo modo, em ação na qual litigava-se acerca de contrato de participação financeira em sociedade por ações, decidiu o Judiciário caber à sociedade o dever de promover à subscrição, no prazo de doze (12) meses, do montante das açóes, correspondentemente ao valor patrimonial de cada ação na data do pagamento do preço pelo aderente, a ser obtido no balanço do período anterior à integtalização, tudo fundado no princípio da boa-fé objetiva ${ }^{57}$. O mesmo dever de proteção conduziu,

55 TJRGS, Ap. Civ. no 70001059641, 6 C. Civ, Rel. Des. Carlos Alberto Álvaro de OLIVErra, j. en 25.04.2001. Na fundamentação do voto do Relator lê-se a seguinte passagem: "O imperativo da boa-fé exigia da demandada conduta que respeitasse a parceira, não tentando se apropriar, em lance de esperteza, do patrimônio desta, iludindo sua confiança e assim tomando inviável a continuação do contrato".

${ }_{56}$ STJ, 4 T, Agr. Reg, no AI n" 47. 901 - 3 - SP, j. 12/09/04, Rel. Min. Ruy Rosado de AGUIAR JÚNIOR. 57TJRGS, Ap. Civ. n 70000457093, $10^{\mathrm{a}} \mathrm{C}$. Civ., j. 25.5.00, Rel. Luiz Ary VESSrNI DE LIMA, a exemplo de outras dezenas de acórdãos similares. 
em contrato de consórcio para a alienação de automóveis, ao dever, da empresa, de restituir as parcelas pagas por consorciado desistente, e não contemplado com o sorteio do bem ${ }^{58}$.

Os deveres de proteção, diretamente derivados do dever geral de colaboração imanente às relações obrigacionais, podem se estender às fases pré e pós contratual. Muito embora não exista, no ordenamento brasileiro, regra similat à do art 1337 do Codice Civile italiano, os juízes brasileiros têm iniciado a construção desta fattispecie com base no princípio da boa-fé objetiva c no dever de proteção das legítimas expectativas dos contratantes e dos pté-contratantes.

Vejamos, em primeiro lugax, as hipóteses de responsabilidade pré-contratual ${ }^{59}$, seja nos casos de recesso injustificado das tratativas - nos quais é máxima a rensão entre o princípio da boa-fé objetiva, de um lado, e a autonomia privada, de ourro-seja na concreção de deveres pré-contratuais de proteção, de informação e de sigilo.

Recente acórdão do Tribunal de Justiça do Rio Grande do Sul, confirmando já iterativa jurisprudência ${ }^{60}$, considerou caber o pagamento de perdas e danos à demandante que havia tratado a locação de imóvel, rompendo o proprietário do imóvel, injustificadamente, as negociações e locando-o a um terceiro. "Tendo bavido tratativas sérias referentes à locação de imóvel, rompida pela requerida sem justificativa, e sem a observância de deveres anexos, decorrentes do princípio da boaféobjetiva", consignou-se no aresto, "cabe indenizaçâo" o.

Em outra hipótese a boa-fé foi utilizada para determinar a responsabilidade póscontratua ${ }^{62}$, imputada ao fornecedor de serviços, que não sustaxa a cobrança de título extrajudicial já pago pelo devedor/consumidor, embora com retardo. Entendeu-se que o

\footnotetext{
${ }^{58}$ TJRGS, Ap. Civ. $n^{\circ} 70000094433-14^{a}$ C. Civ., j. 25.11.99, Rel. Aymoré Roque POTTES DE MELLO.

59 Como aponta MORERRA ALVES, muito embora não haj̧a no Código Civil regra expressa acerca da responsabilidade pré-contratual, a doutrina a aceita, sendo "dominante o entendimento de que a denominada "culpa in contrabendo" se funda na inobservância da boafé. ("A BoarFé Objetiva no Sistetna Contratual Brasileiro", cit, p. 197).

6i) Para o exame de anteriores acórdãos que romperam com a tradição de conectar a responsabilidade pré-contratual à prova do comportatnento culposo veja-se o meu "A Boa-Fé no Direito Privado"; cit,, págs. 472 a 514.

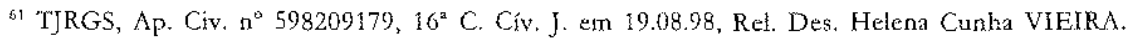

"2 Também aqui há a prévia modelagem pela doutrina. Assim aponta MORExRA ALVES ("A Boa Fé Objetiva no Sistema Contratual Brasileiro", cit., P. 200,) segundo o qual "a doutrina brasileira, apesar do silêncio da legislą̧ão, reconhece a existência de condutas a ser observadas no pertodo pós. contratual (post contractum). Para os que não admitem que, em nosso sistema juridico vigente, se possa ter a boaffé objetiva, sem textos legislativos expressos, como cláusula geral no direito das obrigações para justificar a existência desses deveres secundários, socorrem-se eles da teoria do abuso de direito - e, portanto, segundo a doutrina alemã, de teoria vinculada à boafé objetiva", aludindo à doutrina de Darci BESSONE acerca da interpretaçào dos contratos comerciais.
} 
fornecedor deveria ter determinado ao estabelecimento bancário incumbido da cobrança do título o cancelamento do débito, para que assim fosse evitado um novo - e agora injustificado - protesto do título $o^{63}$. É que os deveres de colaboração implicam em agir positivamente para que o fim contratual seja alcançado e em não agravar a situação da contraparte.

Porém, conforme o caso, o dever de colaboração incumbe ao próprio devedor. Assim é hipótese em que o débito, expresso em duplicata, foi pago com três dias de atraso na própria sede da empresa credora. Ocorre que o tútulo de crédito havia sido entregue à instituição bancária com autorização para cobrança, o que motivou o protesto. O devedor pleiteou, então, indenização por dano moral, o que foi rejeitado. Entendeu o Tribunal que o autor, mesmo ciente do protesto iminente, nada fez para evitá-lo, sequer solicitando à empresa credora que o sustasse, "não agindo com a preocupação daqueles que se sentem atingidos em sua dignidade, não podendo agora pretender indenização por dano moral ${ }^{\varkappa_{4}}$. O dever infringido foi o de colaborar para obstar a prática do ato, "o que poderia ter feito em decorrência da lealdade que deve presidir às relações negociais", como expressa a fundamentação do voto do Desembargador Relator que, apelando à doutrina de Karl Larenz, determinou que a omissão, caracterizando ofensa ao princípio da boa-fé, estabelecia uma concorrência de culpa, de modo a diminuir a responsabilidade da instituição bancária pelo indevido protesto do título.

A proteção da expectativa legitimamente criada pela contraparte é de exponencial relevância também no Direito Administrativo, pois a conduta da Administração Pública, para além da adstrição ao princípio constitucional da moralidade pública ${ }^{65}$ vem ainda revestida pela presunção da legalidade dos atos administrativos. Por esta razão, entendimento longamente mantido acerca da interpretação da lei só pode ser subitamente alterado se houver a proteção das expectativas daqueles que confraram na prática por longos anos mantida. Já se decidiu, neste sentido, em sede de Ação Civil Pública, rejeitar a pretendida anulação de aposentadoria de professoras, especialistas em educação, na medida em que "as requeridas optaram pelo cargo de especialista após longos anos de exercício em sala de aula, época em que vigorava o entendimento administrativo no sentido de o benefício da aposentação

${ }^{6.3}$ TJRGS, Ap. Civy $n^{\circ} 70001037597-9^{2}$ C. Civ, j. 14.6.00, Rel. Paulo de Tarso Vieira SANSEVERINO, em cuja ementa se lê: "(..) Descumprimento do dever de diligência pela fornecedora apelante, decorrente da boafé objetiva, no período pós-contratual, em face da não comprovação das medidas necessárias para o recolhimento do título posto em cobrança bancária".

64TJRGS, Ap. Civ. n" 589078542, $5^{2}$ C. Civ. j. 13.02.90, Rel. Des. Ruy Rosado de AGUIAR JÚNior, in RJTJRGS 148/282.

${ }^{65}$ Constituição Federal, art. 37, caput. 
abranger quem exercia dito cargo", fundando-se a decisão nos princípios da boa-fé objetiva e da segurança jurídica ${ }^{66}$.

A proteção da justa expectativa conduz à adoção de medidas positivas, razão pela qual acórdão do STJ entendeu que, "nas circunstâncias do negócio, o credor tinha o dever, decorrente da boa-fé objetiva, de adotar medidas oportunas para, protegendo o seu crédito, impedir a alienação dos apartamentos a terceiros adquirentes de boa-f $\hat{e}^{267}$. Na espécie, vê-se a conjugação entre, de um lado, o dever de agir segundo a boa-fé objetiva, imposto à incorporadora - esta devetia agir para impedir a alienação dos imóveis, não apenas propondo a ação de execução, mas averbando-a no Registro de Imóveis e informando a empresa financiadora - e, de outro, a boa-fé subjetiva, ou boa-fé crença, dos terceiros adquirentes. Fica á evidente a distinção que há entre agit segundo a boa-fé e agir de boa-fé.

Importante grupo de deveres positivos diz com a prestação de informações, de aconselhamento, de aviso, assim compondo os deveres de informação, em sentido amplo e de veracidade. Atuando, como todos os deveres que decorrem do princípio da boa-fé, em relação a ambos os partícipes do vínculo contratual, o dever de infor mação é imposto, por exemplo, aos segurados que, no contrato de seguro saúde, não podem omitir circunstância relevante. Neste sentido, já decidiu o Trihunal de Jus tiça do Rio Grande do Sul, fundado no princípio da boa-fé objetiva, faltar "direito a segurado que omite circunstância relevante, capaz de aumentar o risco, quanto o mais quando demonstrado o liame de causalidade entre aquela e o fato que se pretende acobertado"66. As companhias seguradoras têm, por sua vez, o dever de prestar informaçóes detalhadas acerca do conteúdo do contrato, no momento da conclusão da avença ${ }^{69}$, cabendo-lhes informar a parte sobretudo sobre as cláusulas de exclusão do benefício ${ }^{70}$. Do mesmo modo o princípio da hoa-fé foi considerado a fonte do dever de sociedade anônima de telefonia informar à contraparte o real valor da venda de ações ${ }^{7 !}$.

bo Comarca de Porto Alegre, $2^{2}$ Vara da Fazenda Pública, Ac. Civ. Pub. $\mathrm{n}^{\circ} 01195487226$, Rel. Juiz Clademix MISSAGIA, j. 07.08.98.

67 ST], RESp. $\Omega^{\circ} 32890 /$ SP, $4^{\text {a }}$ T. j. 12/12/94, Rel. Min. Ruy Rosado de AGUIAR JÚNIOR, in RSTJ 73/ 227.

TuRGS, Ap. Civ. no597019439, 6ª C. Civ, j, 12.11.97, Rel. Des. Antônio Janyr DALLAGNOLL JÚNIOR. 69 TJRGS, Em. Dec. n 196722656 - 6 C. Civ, j. 17.4.97, Rel. Roque Miguel FANK.

${ }^{73}$ TJRGS, Em. Inf. n 598007607 - 30 Grupo de C. Civ., j. 03.4.98, Rel. Antonio Janyr DALL'AGNOL JUNIOR.

${ }_{71}$ TJRGS, Ap. Civ. no 59907596 - 6 C. Civ., j. 05.4.00, Rel. João Pedro FRERRE. 
Por vezes a boa-fé mostra-se a via adequada para a tecepção de doutrinas que se formam no Direito Compatado, o que mais uma vez confirma o nosso "bartolismo". Assim ocorreu com a Teoria da Violação Positiva do Contrato (Positive Vertrageverletzung) cuja origem, nos direitos da "família" tomano-germânica radica-se nas idéias do alemão $\mathrm{H}$. Staub, em 1902, constituindo também conceito versado no direito do common law sob a denominação de anticipated breach of contract.

Afrrma Couto e Silva que esta recepção "baveria de contribuir decisivamente para uma nova concep̧̧ão da relação obrigacional'" $\mathrm{O}$ incumprimento antecipado ocorre quando o devedor, em contrato cujo adimplemento é sujeito a prazo mais ou menos longo, pratica, no rranscorrer desse prazo, atos que, por força da natureza da prestação ou da lei, rornam impossivel o futuro cumprimento. Alguns doutrinadores, notadamente os discípulos de Couto e Silva ${ }^{73}$, passaram a examinar a aplicabilidade desta concepção ao direito brasileiro utilizando, para tal fim, regras legisladas acerca da impossibilidade e da mora, interpretadas segundo o princípio da boa-fé, para entender que "além da impossibilidade, o incumprimento antecipado pode resultar da conduta contrária do devedor, por ação (...) ou omissão (...) ou a declaração do devedor expressa no sentido de que não irá cumprir a prestação ${ }^{574}$, podendo também resultar do chamado "comportamento concludente".

De modelo doutrinário logo migrou o Inadimplemento Antecipado para a modelagem jurisdicional, entendendo-se caracterizado, por exemplo, o dever do construtor de construir, em tempo hábil, a prometida obra industrial em terreno que havia sido adquirido por preço subsidiado, o qual, descumprido, deu enscjo ao provimento da demanda resolutória ${ }^{75}$.

A função otimizadora do conteúdo contratual também opera por via da interpretação e integração de lacunas do contrato. Por evidente, a invocação da boa-fé deve set congruente aos

${ }^{72}$ COUTO E SLVA, Clóvis, "O Princípio da Bóaté no Direito Brasileiro e Português", citado, p. 47.

${ }^{73}$ Assim FRADerA, Vera Maria, "A Quebra Positiva do Contrato", Revista Ajuris, v. 44, Porto Alegre, 1988, p. 144-152, AGUIAR JR, Ruy Rosado, "Extinção dos Contratos por Incumprimento do Devedor (Resolução)", Rio de Janeiro, Aide, 1991, p. 126 e ss e FERRERA DA SRLVA, Jorge Cesa, "A Boa-Fé e a Violaçăo Positiva do Contrato", Porto Alegre, 1999, no prelo.

"AGUIAR JR, Ruy Rosado, "Extinçào dos Contratos por Incumprimento do Devedor ", cit., p. 127.

${ }^{75}$ TJRGS, Ap. Civ. no 596251181 -.. 12 C. Civ., j. 18.3.98, Rel. Armínio José ABREU LIMA DA ROSA. Em sentido similax, TJRGS, Ap. Civ. n $59671530-5^{\circ}$ C. Civ., j. 23.5.96, Rei. Paulo Augusto MONTE LOPES. 
fatos considerados e às demais normas do sistema, tendo-se em conta, notadamente, o programa contratual considerado concretamente, pois, se assim não ocorter, corre-se o risco, não descurável, de a boa-fé servir de anteparo ao parti-pris do julgador.

Decisão em que tal não ocorreu, caracterizando, a meu juízo, o emprego adequado do princípio, é exemplificado por acórdão do Tribunal de Justiça do Rio Grande do Sul ${ }^{76} \mathrm{em}$ matéria de contrato de seguro automobilístico que previa a responsabilidade da seguradora, em caso de infortúnio, para "danos pessoais". Recusando-se a empresa a pagar indenização por danos extrapatrimoniais, por entender que a expressão 'danos pessoais" indicava tão só os "danos corporais", assentou o julgador o primeiro elemento contextual, qual seja, a incindibilidade da "indenização da dor causada pelo dano corporal ou pessoal da do dano moral ou psicológico, forte na bioestrutura de ser bumano, corporal e psicologicamente indissolúvel. A divisão existente-corpo e psiquê-, por evidente, tem ofim apenas pedagógico, para poder melhor estudar a pessoa bumana e não como pretende a seguradora".

Em seguida, recorreu o magistrado ao princípio da boa-fé objetiva, estaruindo que, na dúvida quanto ao significado de cláusula predisposta por uma das partes, "a interpretação deve ser no sentido menos favorável a quem a redigiu", as sim reenviando ao princípio da interpretatio contra preferentem, ou ainda a regra in dubio contra stipulatorem, que, assinalou, 'é especialmente importante boje em dia, devido à difusão dos contratos padronizados e de adesão".

No "ir e vir' entre o texto e o contexto, não esqueceu o julgador da função econômica do contrato. Afirmando constituir este "nada mais que o revestimento jurídico de uma operação econômica" entendeu de "sopesar, na análise de contrato, a satisfação da necessidade, a obtenção do bem que levou as partes a contratarem, e a função econômica que o pacto exerce na vida de relação". Realizada a ponderação entre todos os elementos, de fato e de direito, enfim decidiu: " $E$ a escolba deverá ser feita de modo a assegurar prevalę̧a o interesse que se apresenta mais vantajoso em termos de custo social", o qual, no contexto do programa contratual considetado, apontava à divisão dos prejuízos.

Também considerando a "própria consecução da finalidade do contrato", o que é dizer, a sua objetiva causa, há decisão em matéria de contrato de seguro-saúde cuja cláusula de "vigência temporátia" foi tida como abusiva, por impeditiva do alcance daquela concreta finalidade ${ }^{77}$. A interpretação do contrato, com o conseqüente afastamento da cláusula abusiva, ocorreu complessivamente, fazendo o relaror apelo à doutrina de Cláudia Lima Marques ${ }^{78}$ que examinou a boa-fé no âmbito das relações de consumo.

\footnotetext{
${ }^{76}$ TJRGS, EI ${ }^{\circ} 196032114,4^{\circ}$ Grupo de C. Civeis, Rel. Des. Roberto Expedito da CUNHA MADRID, j. em 17.3.97.

"TJRGS, Ap. Civ. n $596230888,5^{2}$ C. Civ., Rel. Des. Luiz Felipe BRASIL SANTOS, j. em 5.6.97.
} 
Para alérn destas hipóteses - aqui lembradas a titulo exemplificativo - outras se verificam para promover o concreto reequilíbrio das prestações contratuais ameaçado seja pela inexistência de sinalagma genético, seja pela quebra do sinalagma funcional, seja ainda, notadamente no âmbito das relações de consumo, pela inserção de cláusulas abusivas.

\section{B) A BOA-FÉ E O EQUULÍBRIO CONTRATUAL}

O relativo equilíbrio entre prestação e contraprestação que deve presidir os contratos bilaterais e sinalagmáticos é quebrado ou pela lesão ou pela excessiva onerosidade. Ambas hipóteses hoje em dia têm específica previsão legal no âmbito das relações jurídicas de consumo e no Código Civil projetado. Porém, no campo do direito comum é por vezes a boa-fé chamada para ensejar a revisão das prestações ${ }^{79}$ lesionárias ou excessivamente onerosas $^{80}$, muito embora nem sempre os juízes realizem o correto discrime entre ambas.

O instituto da lesão, conquanto previsto nas Ordenações Filipinas (Livro IV, Titulo XIII) do Reino português, constituindo, pois, figura antiquíssima no direito luso-brasileiro, inclusive regulado por Teixeira de Freitas na Consolidação das Leis Civis (art. 359), estava ausente de nossa legislação desde $1916^{81}$, tendo sido reincorporado no domínio das relações de consumo pelo Código de Defesa do Consumidor, de $1990^{82}$. Manteve-se aí a nossa tradição de considerar a lesão (laesio enorme, e enormissima) defeito objetivo, diferentemente dos sistemas de raiz francesa. Também o Projeto de Código Civil a prevê, no art. 157.

Segundo Moreira Alves, no concernente à lesão o Projeto se afastou também do sistema alemão e do iraliano - e, portanto, do adotado pelo Código Civil português de

\footnotetext{
${ }^{78}$ MARQUeS, Cláudia Lima, "Contratos no Código de Defesa do Consumidor", São Paulo, Revista dos Tribunais, $3^{\text {a }}$ edição, 1999.

${ }^{79}$ TJRGS, Ap. Civ. n 196105167, 6² C. Cív. j. em 8.8.96, Rel. Des. Armínio José ABREU LIMA DA ROSA, e assim ementada: "Contrato de financiamento. Excessiva Onerosidade. Embora náo se aplique, diretamente, aos contratos bancários, o CDC pode ser objeto de utilização analógica quando manifesta a excessividade de interesses remuneratórios do capital. Caso em que, de resto, caberia recorrer a princípios gerais de Direito e evitar Locupletamento indevido de uma das partes. Mantença da $T R$, juros moratórios de $1 \%$ ao mês e multa. Apelo provido em parte".

8i) No tocante à revisão por quebra da base negocial objetiva o leading case foi a Ap. Civy $\mathrm{n}^{\circ} 5880591113$, TJRGS, $3^{\text {a }}$ C. Cív. j. 6.12.88, Rel. Des. Ruy Rosado DE AGUMAR JR.

"Na década de 50 a lesão foi recebida no Direito penal através da figura da usura, prevista na Lee $n^{\circ} 1521$, de $26 / 12 / 51$, art. $4^{\circ}$.

${ }^{82}$ Código de Defesa do Consumidor, Lei $\mathrm{n}^{\circ} 8.078$, de 11 de setembro de 1990 , art. $6^{\circ}$, inciso V, primeira parte.
} 
1967 - não se preocupando em punir a atitude maliciosa do favorecido, mas em tutelat o lesado. Assim sendo, a lesão ocorre "quando uma pessoa, sob premente necessidade, ou por inexperiência, se obriga a prestação manifestamente desproporcional ao valor da prestação oposta", admitindo a lei a suplementação da contraprestação, ou a redução do proveito, para afastar a consequência anulatória ${ }^{83}$. A lesão introduzida pelo Projeto é um defeito que se instala no momento da conclusão do negócio, já impedindo a formação do sinalagma genético, razão pela qual, no meu entender, pressupõe contrato bilateral e comutativo, mensurando-se o desequilíbrio tendo-se em conta o contrato como uma totalidade, isto é, não devem ser consideradas apenas as prestações principais.

Para além da lesão, o Código de Defesa do Consumidor e o projetado Código Civil também permitem ao juiz revisar o contrato quando fatos supervenientes à sua conclusão tornatem excessivamente onerosa a prestação, embora o façam por modos distintos, exigindo distintos pressupostos.

O Código do Consumidor não exige que a desproporção tenha por causa acontecimentos extraordinários ou imprevisíveis, razão pela qual, conquanto a referência, na lei, à excessiva onerosidade $^{84}$, mais proximamente se trata da adoção da Teoria da Base Objetiva do Negócio. Nesta é imediata a correlação entre a revisão do contrato e o princípio da boa-fé, o que, de resto, vem do Direito alemão, como relata Hartenhauer ${ }^{85}$, ao comentar a pioneira sentença de 28 de novembro de 1923 do Tribunal Supremo ${ }^{86}$. Igualmente Clóvis do Couto e Silva estabelecera

${ }^{83}$ Assim pronunciou-se MOREIRA ALVES ao dar parecer sobre a emenda supressiva do Senador Gabriel Hermes: "A lesão ocorre quando bá a ustra real. Não bá, na lesão, ao contrário do que ocorre com o estado de perigo, que vicie a simples oferta. Ademais, na lesão não é preciso que a outra parte saiba da necessidade ou da inexperiência: a lesão é objetiva. Já no estado de perigo é preciso que a parte beneficiada saiba que a obrigação foi assumida pela parte contrária para que esta se salve de grave dano levando-se em conta, pois, elemento subjetivo").In "O Projeto de Código Civil no Senado", Tomo II, Brasília, Senado Federal, 1998, p. 015.

${ }^{84} \mathrm{CDC}\left(\mathrm{Lei} \mathrm{r}^{\circ} 8.078 / 90\right.$, art. $6^{\circ}$, inciso $\mathrm{V}$, primeira parte.

"5 HATTENHAUER, Hans, "Conceptos Fundamentales del Derecho Civil", trad, espanhola, Ed. Ariel, Barcelona, 1987, p. 90.

${ }^{86}$ RGZ, 107, 78, 87 e ss, apud HATTENHAUER, op., e p., acima referidas. Por esta decisão precisou-se que não era somente o devedor, mas ambos os partícipes da relação contratual que deveriam suportar, conjuntamente, os prejuizos da inflação, fundando-se o decidido justamente na cláusula geral da boa-fé objetiva inscrita no parágxafo 242 do Código Civil. Estabelecido que a adstrição ao pactuado (pacta sunt servanda) devia amoldar-se à boa-fé e aos costumes do tráfego jurídico, reformulou-se, no direito alemāo, a teoria da base do negócio e o antigo princípio da equivalência, com o que, afima HATTENHAUER, "a teoria das relaçöes obrigacionais abriw-se para novos caminhos". 
esta correlação ${ }^{87}$, acolhida pela jurisprudência brasileira ${ }^{88}$. Já o Projeto de Código Civil, no art. 478 prevê a resolução por excessiva onetosidade nos moldes como este instituto é previsto em sua matriz italiana, podendo, na forma do art. 480 , caber a revisão para evitar a excessiva onerosidade. Se, contudo, a revisão conduzir a que o contrato perca o seu sentido original como tegramento objetivo de interesses dotado de determinada função econômicosocial, aí sim caberá o remédiø extremo da resolução.

Não vigorando ainda o novo Código, a jurisprudência faz apelo à boa-fé objetiva. $O$ Tribunal de Justiça do Rio Grande do Sul decidiu revisar contrato com fundamento no princípio da boa-fé, entendendo cabível a ação revisional de contrato de locação, por excesso de onerosidade, uma vez que indexação do valor locatício fora pactuada pela variação do dólar americano, que sofrera súbita valorização em face do real. Nesre caso, embora inaplicável o Código de Defesa do Consumidor, pois não configurada a relação de consumo, caberia, "diante das peculiaridades da situação econômica vigente após a edição do Plano Real, em que os indices inflacionários tem sido insignificantes (...) a análise de cada caso a fim de se verificar a possibilidade ou não de revisão dos contratos pretendidos revisar". Na espécie, considerando a indexação dos encargos contratados pela variação do dólar americano e a elevação súbita deste, pateceu ao Judiciário "perfeitamente possivel a revisão do contrato firmado pelas partes, com base na boa-fé objetiva ${ }^{g 9 "}$.

É o mesmo princípio, por igual, que está no substrato das regras do Código de Defesa do Consumidor que preceituam a nulidade de cláusulas abusivas, que desequilibrem o contrato e que sejam iniquas, atentatórias à boa-fé e à equidade $\%$. Entre outros inúmeros casos que poderiam ser aqui lembrados está a decisão que cominou de nulidade, por abusividade, já que atentatória à boa-fé objetiva, cláusula de contrato de seguto que estabelece, como parâmetro à indenização, o preço de mercado do bem, determinando devesse o mesmo ter em conta o valor indicado na apólice de seguro ${ }^{91}$.

Por fim, o modelo jurisprudencial da boa-fé no Direito Brasileiro tem sido ainda composto por hipóteses em que a boa-fé opera negativamente, impedindo ou sancionando condutas contraditórias e vedando o exercício de direitos subjetivos ou de direitos porestativos.

\footnotetext{
${ }^{87}$ COUTO S SILVA, Clóvis, "Teoria da Base do Negócio", São Paulo, RT v. 655, 1990.

${ }^{B}$ Exemplificativamente, Ac. TJRGS, Ap. Civ. n ${ }^{\circ} 588059113,5^{3}$ C. Civ., Rel. Des. Ruy Rosado de AGUIAR JR., j. em 6.12 .88 .

89 TJRGS, Ap. Civ. $n^{\circ} 70000078626,15^{2}$ C. Civ, Rel. Des. Ricardo RAUpp RUSCHEL, j. em 22.3.2000.

${ }^{20}$ CDC, art. 51 , parágrafo $4^{\circ}$.

9" TJRGS, Ap. Civ. ${ }^{\circ} 599443694$ - 1 C. de Férias Civ., j. 21.10.99, Rel. Paulo de Tarso Vieira SANSEVERINO, a exemplo de outros acórdãos.
} 


\section{C) A BOA.FÉ COMO LIMITE AO EXERCÍCIO DE DIREITOS}

Ao operar negativamente, por forma a impedir ou a sancionar condutas contraditórias, a boa-fé é reconduzida à máxima que proíbe venire contra factum proprium. A expressão "venire contra factum proprium" indica uma especificação da antiga Teoria dos Atos Próprios tradutora de princípio geral que tem como injurídico o aproveitamento de situações prejudiciais ao alter para a caracterização das quais tenha agido, positiva ou negativamente, o titular do direito ou faculdade ${ }^{92}$. O princípio atua em todos os "ramos" do Direito, tendo sua raízes no Direito Romano que, sistematizado no Direito Intermédio, deu causa ao brocardo adversus factum sum quis venire non potest ${ }^{93}$. Todavia, já no Digesto $(50,17,75)$, Papiniano assinalava a inadmissibilidade de alguém modificar de critério em prejuízo alheio ${ }^{94}$, o que se estende modernamente ao Direito Civil, Administrativo, Penal e Processual com particular inrensidade.

Trata-se de uma regra de fundo conteúdo ético que, por refletir princípio geral, independe de recepção legislativa, verificando-se nos mais diversos ordenamentos como uma vedação genérica à deslealdade. Na proibição do venire incorre quem exerce posição jurídica em contradição com o comportamento exercido anteriotmente, verificando-se a ocorrência de dois comportamentos de uma mesma pessoa, diferidos no tempo, sendo o primeiro (o factum proprium) contrariado pelo segundo ${ }^{95}$.

A proibição da contraditoriedade no processo também é conhecida mediante o instituto anglo-saxão da estoppel, pelo qual entende-se estabelecida uma presunção iure et de iure que impede juridicamente que uma pessoa afirme ou negue a existência de um fato determinado, em virtude de haver anteriormente executado um ato, feito uma afirmação ou formulado uma negativa em sentido precisamente oposto, como explica o jurista argentino Alejandro Borda em sua clássica monografia ${ }^{\%}$. Pode indicar, outrossim, um freio erguido à

\footnotetext{
${ }^{92}$ Assim escrevi em "A Boa-Fé no Direito Privado", cit., p. 462.

${ }_{3}$ Conforme BORDA, Alejandro, "La Teoria de los Actos Proprios", Buenos Aires, Abeledo-Perrot, 3 " edição atualizada e ampliada, 2000 , p. 13.

44 Idem, p. 14.

${ }^{2}$ Conforme MeNezes CoRdeiro, Antonio M., "Da Boa-Fé no Dircito Civil", Coimbra, Almendina, 1989, p. 745.

26 P. cit., p. 25 e ss.
} 
pretensão de quem reclama algo em aberta contradição com o que havia anteriormente aceitado, como explica o também argentino Moisset de Espanés ${ }^{97}$.

Este breve delineamento conceitual explica a razão pelo qual o venire tem tido progressiva aceitação nos Tribunais. Em matéria de conrrato de seguro, já decidiu o Superior Tribunal de Justiça que a boa-fé veda o comportamento contraditório inclusive na fase processual, por forma a incidir na fixação do dies a quo para o cálculo da prescrição extintiva, pois se a recusa da seguradora a aceitar os dados de que dispunha em seu departamento médico como suficientes para caracterizar a incapacidade coberta pelo seguro, e a não-aceitação do laudo apresentado pelo segurado ao propor a ação conduziu à realização de perícia em juízo, não poderia ensejar a invocação daquelas datas dos laudos não-aceitos para a fluência do prazo prescricional, esratuindo a decisão: "a boa fé objetiva, que também está presente no processo, não permite que uma parte alegue contra a outra um fato que ela não aceita e para o qual exige prova judicializada' ${ }^{38}$.

Também pela invocação ao venire a Administração Pública viu limitada a pretensão de exigit a devolução de vencimentos pagos a servidor durante o período de concessão de licença remunerada, a qual, constatou-se posteriormente, havia sido equivocadamente concedida ${ }^{\text {"s }}$, em outra hipótese sendo a boa-fé foi o limite que impediu a revisão de contrato que já fora alvo de transação, em anterior oportunidade ${ }^{\mathrm{t} / \%)}$.

Pela mesma via da boa-fé objetiva têm a jurisprudência brasileira acoilhido também o conceito de Adimplemento Substancial, oriundo do direito do common law, pelo qual limita-se ou se impede o exercício do poder formativo (potestativo) de resolução contratual nos casos em que a prestação contratual, embora não totalmente cumprida, foi "substancialmente adimplida".

O adimplemento substancial significa, segundo o magistério de Clóvis do Couto e Silva, o cumprimento próximo do resultado final, que exclui o direito de resolução, facultando apenas o pedido de adimplemento e de perdas e danos ${ }^{1 / 3 !}$. Fazendo expressa remissão a esta

${ }^{97}$ MOISSET DE ESPANÉS, Luis, "La Teoria de los Propios Actos y la Doctrina y la Jurisprudencia Nacionales", apud BORDA, op. cit, p. 26.

98 STJ, REsp a 18.4573/SP, STJ, 4 T., Rel. Min. Ruy Rosado de AGUTAR JÚNIOR, DJ. 15.03.99. p. 241. Também no STJ, e fundado na máxima do venire o RESP 95535/SP, DJ 14.10.96, p. 39015.

TJRGS, Ap. Civ. $n^{\circ} 597200237-3^{\circ}$ C. Civ. j.04.6.98, Rel. Perciano CASTILHOS BeRTOLUCI.

${ }^{100}$ TJRGS, Ap. Civ. n 598474237 - 20 C. Civ., j.15.2.00, Rel. José Aquino FLORES DE CAMARGO.

101 COUTO E SILVA, Clóvis, "O Princípio da Boaffé no Direito Brasileiro e Português", cit., pp. 56 e 57. 
doutrina ${ }^{\text {j02 }}$, já decidiu o Tribunal de Justiça do Rio Grande do Sul que "o comprador que pagou todas as prestações de contrato de longa duração, menos a última, cumpriu substancialmente o contrato, não podendo ser demandado por resolução"103. Em outra hipótese considerou-se atentatório contra a boa-fé almejar-se a reintegração de posse de bem alienado fiduciariamente quando o devedor adimplira a quase totalidade do débito (vinte e uma de vinte e quatro prestações) ${ }^{104}$.

A mesma doutrina do Adimplemento Substancial fundamentou decisão adotada ao apreciar o Judiciário lide decorrente de con rrato de compra e venda de imóvel que apresentara defeitos na construção. Entendeu-se que, não sendo estes suficientes para caracterizar o inadimplemento do vendedor, incidiria a regra do art. 1.056 do Código Civil, ensejadora de perdas e danos, e não a do parágrafo único do art. 1.092, que consagra a resolução por inadimplemento. Isto porque o apartamento, objeto do contrato, conquanto apresentasse condições deficientes para a habitação, e que poderiam ser sanadas, não era maculado por vícios quanto à sua estabilidade e solidez. Assim, manteve-se o contrato, afastando-se a pretensão resolutória, condenando-se, porém, o vendedor ao pagamento de indenização suficiente para suportar as despesas com a reforma do imóvel, aré a sua integral habitabilidade ${ }^{105}$.

Por igual atua a boa-fé como limite ao exercício de direitos subjetivos nos casos indicados sob a denominação de supressio. Segundo tecente acórdão do Tribunal de Justiça do Rio Grande do Sul ${ }^{106}$, esta "constitui-se em limitação ao exercício de direito subjetivo que paralisa a pretensão em razão da boa-fé objetiva". Exige-se, para a sua configuração, "(I) o decurso de prazo sem exercício do direito com indícios objetivos de que o direito não mais seria exercido e (II) desequilíbrio, pela ação do tempo, entre o benefício do credor e o prejuízo do devedor".

Diferentemente da supressio, que indica o encobrimento de uma pretensão, coibindose o exercício do direito em razão do seu não exercício, por determinado período de tempo, com a conseqüente criação da legítima expectativa, à contraparte, de que o mesmo não seria

\footnotetext{
${ }^{102}$ Também explicitada por BECKER, Anelise, "A doutrina do adimplemento substancial no Direito Brasileiro e em perspectiva comparativista", Revista da Faculdade de Direito da Universidade Federal do Rio Grande do Sul, vol. 9, Porto Alegre, 1993, pP. 60-77.

103TJRGS, Ap. Civ. n 588012666, j. 12. 04.88, Rel. Des, Ruy Rosado de AGUIAR JÚNIOR.

on TJRGS, Ag. I. $n^{\circ} 70000027623-1^{*} \mathrm{C}$. de Férias Cív, j. 18.11.99, Rel. Des. Paulo de Tarso VIEIRA. SANSEVERINO. Em sentido similax, os Agravos de Instrumento ns 70000539908 - 14" C. Cív., j. 16.12.99, e $7001005586-14^{2}$ C. Civ., j. 29.6.00, ambos tendo como Rel. o Des. Aymoré Roque POTTES DE MELLO.

${ }^{5}$ TJRGS, Ap. Civ. n ${ }^{\circ} 588016147,5^{2}$ C. Civ. Rel, Des. Ruy Rosado de AGUIAR JR., j. em 3. 4. 1988. ${ }^{106}$ TJRGS, Ap. Civ. $\mathrm{n}^{\circ} 70001123561,2^{a} \mathrm{C}$. Civ., j. 28.06.2000, Ret. Des Maria Isabel de AZEVEDO SOUSA.
} 
utilizado, outra figura, a surrectio aponta ao nascimento de um direito como efeito, no tempo, da confiança legitimamente despertada na contraparte por determinada ação ou comportamento. Assim ocorreu ao examinar-se lide decorrente de contrato de locação $0^{107}$ que previa a resiljção unilateral, mediante prévio aviso de sessenta $(60)$ dias à contraparte, por carta protocolada que expressasse o poder extintivo da denúncia contratual, contemplando, outrossin, a possibilidade de renovação do contrato, desde que, por meio de carta protocolada, a parte interessada assim expressasse vontade com antecedência mínima de sessenta (60) dias. Por um periodo superior a doze (12) anos, as partes vinham prorrogando a avença, sempre mediante o recurso à formalidade do envio de cartas. Em certa ocasião, contudo, em resposta ao pedido de prorrogação, feita pelo locatário, respondeu a locadora que não pretendia tenová-lo. $O$ debate centrou-se na argumentação, do lado locatário, do "direito à automaticidade" da prorrogação, de outro, por parte da locadora, da legitimidade de sua pretensão a resilir a avença.

A decisão, embora considerando caber razão à locadora, no sentido da inocorrência de uma "automaticidade" da prorrogação contratual, uma vez terem as partes sempre observado o requisito da forma contratualmente prevista, entendeu, porém, obstado o poder formativo extintivo de resilição (denúncia contratual), apontando, consequentemente, ao nascimento do direito à prorrogação pelo fato de, no período imediatamente anterior ao dies ad quem do prazo contratual, ter a locadora imposto, ao locarário, a realização de despesas com reformas no prédio, levando-o a acreditar que não romperia, inopinadamente, uma tradição de doze (12) anos no sentido da continuidade da relação contratual. Nos fundamentos do acórdão está o princípio da boa-fé objetiva, como proteção à confiança traída.

Estes exemplos são suficientes, no meu entender, para demonstrar como vem a jurisprudência brasileira construindo a normatividade do princípio da boa-fé objetiva como norma reitora da proteção da confiança, da colaboração e da consideração com os interesses aiheios que presidem a relação obrigacional. Neste modelo em plena construção é necessário, no entanto, atentar para três pontos imporrantes.

O primeiro está em que o princípio da boa-fé objetiva é a via para a concretização, no domínio das relações obrigacionais, notadamente as contratuais, dos deveres que defluem da diretriz constitucional da solidariedade social ${ }^{108}$. A doutrina e jurisprudência italianas têm, nesre aspecto, uma lição a ensinar, na medida em reconduzem os deveres de agir

\footnotetext{
${ }^{1177}$ TJRGS, IM n ${ }^{\circ} 197280175,1^{2}$ C. Cív, j. 19.8.98, Rel. Des. Irineu MARIANI.

${ }^{11.88}$ Escrevi sobre o tema in" Mercado e solidariedade social entre cosmos e taxis: a boa-fé nas relaçoes de consumo", ensajo integrante de "A Reconstrução do Direito Privado - reflexos dos princípios, diretrizes e garantias constitucionais no Direito Privado", no prelo.
} 
segundo a boa-fé no período contratual e pré-contratual à diretriz constitucional da solidariedade social ${ }^{109}$, reconhecendo que esta, por sua hierarquia constitucional, "qualifica o complexo das atividades juridicamente relevantes dos sujeitos, ai compreendidas as prénegociais" 110 , constituindo a boa-fé "um aspecto do princípio geral (que) exprime a necessidade de um espírito de colaboração recíproco entre os contraentes e em condições de paridade, em função da realização da pessoa bumana e de seu pleno e igual desenvolvimento"'11.

Com efeito, constituindo "norma-princípio" "112, mais propriamente um modelo, a boa-fé objetiva em sua concreta atuação opera articuladamente com outros princípios e com outras regras. No substrato desta técrica combinatótia está a consideração das transformações que sofre a ordem econômica em razão da chamada "globalização" e que utiliza as normas vagas, em combinação com normas imperativas, juntamente com outros procedimentos, tais como novas formas de articulação negocial, para minimizar os riscos das fissuras econômico-sociais, tendendo a assegurar, como assinala José Eduardo Faria, "um equilíbrio substantivo" entre os partícipes das telações econômico-sociais e criando, na medida do possível, "as condições para a consecução de padrões básicos de solidariedade e cooperação" ${ }^{113}$.

O segundo traço a assinalar diz com a responsabilidade da doutrina ao apontar os modelos hermenêuticos que auxiliarão o juiz, e mesmo ao legislador, na elaboração dos modelos jurídicos. Vivemos em um tempo que tem pressa, mas a atividade doutrinária não pode prescindir da reflexão, do tempo de maturação das idéias e das novas concepções, equilibrando-se na tensão entre o apontar de novos caminhos, constitutivo da sua missão antecipante de novas soluções, e a necessidade de ponderação, a cada dia mais dificultosa e

\footnotetext{
${ }^{109}$ Neste sentido PIGNATARO, Gisela, "Buona Fede oggettiva e rapporto precontratuale: gli ordinamenti italiano e francese, Salemo, Edizioni Scienufiche Italiane, 1999, p. 47, e MONATERf, Pier Gruseppe, La Responsabilità Contrattuale e Precontrattuale, Turim, UTET, 1998, p. 377 e ss, com indicaçăo da jurisprudência.,

${ }^{10}$ PIGNATARO, Gisela, "Buona Fede oggettiva e rapporto precontrattuale, cit, p. 48, traduzi.

"1" PIGNATARO, Gisela, "Buona Fele oggettiva e sapporto precontrattuale, cit, p. 48, traduzi.

${ }^{1 t 2}$ Utilizo aqui as lições de ALEXY, Robert, "Teoria de Los Derechos Fundamentales", Madri, Ėd. Centro de Estudios Constitucionales, 1993, em especial pp. 81 a 93.

113 FARIA, José Eduardo, "O Direito na Economia Globalizada", Tese apresentada ao concurso para Professor Titular de Deparamento de Filosofia e Teoria Geral do Direito da Universidade de São Paulo, 1999 , p. 304.
} 
necessána porque, como disse Hannah Arendt"114, a irreflexão, "a imprudência temerária ou a irremediável confusão ou a repetição complacente de "verdades" que se tomaram triviais e vazias parece ser uma das principais características do nosso tempo".

O terceiro traço, por fim, diz com a missão da jurisprudência. Se o Direito não é um "dado" que o jurista recebe, "é uma tarefa que o concita a um ingente esforfo e a uma profunda responsabilidade ${ }^{115}$ ", devemos considerar que o princípio da boa-fé objetiva, justamente por configurar norma vaga, semanticamenre aberta, carreia, para o juiz, um extraordinário acréscimo de sua responsabilidade. Não pode nem recair no crasso decisionismo, nem no voluntarismo, tanto primário quanto perigoso aos valores da Democracia.

Se é bem verdade que o princípio enseja uma tarefa de reconstrução dogmática do Direito obrigacional, também é verdadeiro que esta não é absolutamente uma tarefa arbitrária. A invocação da boa-fé contratual está "contida nos limites da realidade do contrato, sua tipicidade, estrutura e funcionalidade, com aplicação dos princípios admitidos pelo sistema"116. Toda e qualquer reconstrução dogmática está, em primeiro lugar, atada aos valores e diretivas do ordenamento, os quais exigem do juiz não apenas ato de vontade, mas, fundamentalmente, ato de conhecimento e de responsabilidade, razão pela qual a exigência constitucional da motivação da sentença deve ser acrescida pela mais completa explicitação dos elementos de fato e de direito que ensejaram, na hipótese examinanda, a invocação da boa-fé. Em segundo lugar depende do domínio técnico do magistrado acerca dos mecanismos - metodológicos e dogmáticos - que permirem a solução justa nos quadros do ordenamento.

Bem sopesadas estas condicionantes, creio que, com passos às vezes hesitantes, nem sempre adequados, mas com a coragem para enfrentar os desafios cotidianamente colocados pela tensão entre o Direito e a realidade, a jurisprudência brasileira começa a construir o seu próprio modelo da boa-fé objetiva.

${ }^{114}$ ARENDT, Hannah, "A Condiçăo Humana", $5^{2}$ edição, Rio de Janeiro, Forense Universitária, 1991, p. 13. "15 A expressão é de CASTANHEIRA NEVES, "O Papel do Jurista no Nosso Tempo", ora in Digesta, vol. $1^{\circ}$, Coimbra, Coimbra Editora, 1995, p. 32.

"16 AGUIAR JR, Ruy Rosado de, "A Boa-Fé nas Relações de Consumo", Revista Direito do Consumidor vol. 14, São Paulo, 1995 p. 25. 


\section{REFERÊNCIAS BIBLIOGRÁFICAS}

AGUIAR JR, Ruy Rosado, "Extinção dos Contratos por Incumprimento do Devedor (Resolução)", Rio de Janeiro, Aide, 1991.

“A Boa-Fé nas Relações de Consumo", Revista Direito do Consumidor vol. 14, São Paulo, 1995.

ALMEIDA COSTA, Mario Júlio, "Romanismo e Bartolismo no Direito Português", Boletim da Faculdade de Direito da Universidade de Coimbra, vol. XXXVI, 1960

. "Direito das Obrigações", Almendina, Coimbra, 8ª edição, 2000.

ALEXY, Robert, "Teoria de Los Derechos Fundamentales", Madri, Centro de Estudios Constitucionales, 1993.

ARENDT, Hannah, "A Condição Humana", Rio de Janeiro, Forense Universitátia, 5 edição, 1991 .

BECKER, Anelise, "A doutrina do adimplemento substancial no Direito Brasileiro e em perspectiva comparativista", Revista da Faculdade de Direito da Universidade Federal do Rio Grande do Sul, vol. 9, Porto Alegre, 1993.

BORDA, Alejandro, "La Teoria de los Actos Proprios", Buenos Aires, Abeledo-Perrot, 3 " edição, 2000.

BRAUDEL, Fernand, "História e Ciências Sociais", tradução portuguesa de Rui Nazaré, Lisboa, Editorial Presença, $4^{a}$ edição, 1982.

CASTANHEIRA NEVES, "O Papel do Jurista no Nosso Tempo", Digesta, vol. 1”, Coimbra, Coimbra Editora, 1995, p. 32.

COUTO E SILVA, Clóvis, "A Obrigação como Processo", São Paulo, José Bushatsy Editor, 1976.

- "O Principio da Boa-Fé no Direito Brasileiro e Português", in "Estudos de Direito Civil Brasileito e Português", São Paulo, Revista dos Tribunais, 1986. . "Teoria da Base do Negócio, São Paulo, RT v. 655, 1990.

FARIA, José Eduardo, "O Direito na Economia Globalizada", Tese apresentada ao concurso para Professor Titular de Departamento de Filosofia e Teotia Getal do Direito da Universidade de São Paulo, 1999.

FERREIRA DA SILVA, Jorge Cesa, "A Boa-Fé e a Violação Positiva do Contrato", Porto Alegre, 1999, inédito (no prelo). 
FRADERA, Vera Maria, "A Quebra Positiva do Contrato", Porto Alegre, Revista Ajuris, v. 44, 1988.

GOMES, Orlando, "Transformações Gerais do Direito das Obrigaçōes", São Paulo, Revista dos Tribunais, $1^{a}$ edição, 1967.

HATTENHAUER, Hans, "Conceptos Fundamentales del Derecho Civil", trad. espanhola, Barcelona, Ariel, 1987.

HESPANHA, Antonio Manuel, "Panorama da Culiura Jurídica Européia", Lisboa, Publicações Europa-America, 1997.

MARQUES, Cláudia Lima, "Contratos no Código de Defesa do Consumidor", São Paulo, Revista dos Tribunais, $3^{2}$ edição, 1999

MARTINS-COSTA, Judith, "A Boa-Fé no Direito Privado", São Paulo, Revista dos Tribunais, 1999.

"O Projeto de Código Civil Brasileiro: em busca da "ética da situação", Porto Alegre, Revista Jurídica vol. 282, 2001.

_ـ__.. "Mercado e solidariedade social entre cosmos e taxis: a boa-fé nas relações de consumo", ensaio integrante de "A Reconstrução do Direito Privado - reflexos dos princípios, diretrizes e garantias constitucionais no Direito Privado", no prelo.

MENEZES CORDEIRO, Antonio M., "Da Boa-Fé no Direito Civil", Coimbra, Almendina, 1989.

MONATERI, Pier Giuseppe, La Responsabilità Contrattuale e Precontrattuale, Turim, UTET, 1998.

MOREIRA ALVES, José Carlos, "A Boa-Fé Objetiva no Sistema Contrarual Brasileiro", Revista Roma e America, vol. 7/99, Roma, 1999.

MÜLLER, Friedrich, "Discours de la Méthode Juridique", Paris, PUF, 1996.

PARADISI, Bruno, "Questioni Fondamentali per una Moderna Storia del Diritto", in Quaderni Fiorentini per la Storia del Pensiero Giuridico Moderno, vol. 1, Firenze, 1972 ,

PIGNATARO, Gisela, "Buona Fede oggettiva e rapporto precontrattuale: gli ordinamenti italiano e francese, Salerno, Edizioni Scientifiche Italiane, 1999.

REALE, Miguel. "Fontes e Modelos no Direiro - para um novo paradigma hermenêutico", São Paulo, Saraiva, 1994.

"Para uma teoria dos modelos jurídicos", in "Estudos de Filosofia e de Ciência do Direito", São Paulo, Saraiva, 1978.

Literárias, 1981. 
SERPA LOPES, Miguel Maria. "Curso de Direito Civil", Rio de Janeiro, Freitas Bastos, $1^{\text {a }}$ ediçã̃o, 1957.

SILVEIRA, Alípio, "A Boa-Fé no Código Civil", Tomos I e II, São Paulo, Editora Univetsitária de Direito, 1973.

VARELA, Laura Beck, "Algumas Contribuiçôes da Ciência Histótica à Tatefa do Hisroriador do Direito", in Revista da Faculdade de Direiro da Universidade Federal do Rio Grande do Sul, vol. 18, Porto Alegre, 2000.

ZACCARIA, Giuseppe, "Sul concetto di positività nel diritto", in Diritto Positivo e Positività del Diritto, Turim, Giappichelli, 1991.

L'Arte dell'interpretazione, Pádua, Cedam, 1990.

\section{DECISÕES CITADAS}

STF:

RE $158448 / \mathrm{MG}$.

STJ:

Agr. Reg. no AI n ${ }^{\circ} 47.901-3-S P$;

AGA 47901;

EDRESP 167691 ;

RESP 256274; RESP 107211; RESP 80036; RESP 32890; RESP 3714/RS; RESP 7187/SP; RESP 85521/PR; RESP 101061/PB; RESP 157841/SP; RESP 5932/RS; RESP 158728/RJ; RESP 18.4573/SP; RESP 95535/SP.

REMS n ${ }^{\circ}$ 6183-MG.

ROMS 6183; ROMS 1694/RS; 


\section{TJRGS}

Ap. Civ. $n^{\circ}$ 598225720; Ap. Civ. $n^{\circ}$ 597019439; Ap. Civ.194.045.472; Ap. Civ. ${ }^{\circ}$ 596131060; Ap. Civ. $n^{\circ}$ 598037257; Ap. Civ. n 70001059641 ; Ap. Civ. $n^{\circ} 70000457093$, Ap. Civ. nº 70000094433; Ap. Civ. n. ${ }^{\circ} 598209179$, Ap. Civ. nº 70001037597; Ap. Civ. nº 589078542; Ap. Civ. n597019439; Ap. Civ. ${ }^{\circ}$ 59907596; Ap. Civ. n 596251181; Ap. Civ. $n^{\circ} 59671530$; Ap. Civ. n ${ }^{\circ}$ 596230888; Ap. Civ. n 5880591113; Ap. Civ. n 196105167; Ap. Civ. n 588059113; Ap. Civ. $n^{\circ}$ 70000078626; Ap. Civ. nº 599443694; Ap. Civ. ${ }^{\circ}$ 597200237; Ap. Civ. n 598474237; Ap. Civ. n 588012666; Ap. Civ. nº 588016147, Ap. Civ. nº 70001123561;

Agr. I. n 70000027623 ; Agr. I. n ${ }^{\circ} 70000539908$; Agr. I 7001005586

Em. Dec. $n^{\circ} 196722656$;

Em. I. n 598007607; Em. I n 196032114 ;

IM n ${ }^{\circ} 197280175$;

$2^{2}$ Vara da Fazenda Pública, Comarca de Porto Alegre, Ac. Civ. Pub. nº 01195487226. Justiça de São Paulo - Primeiro Colégio Recursal dos Juizados Especiais Cíveis da Capital - Recursos nº $7.959 ; 7.766 ; 7747$ e 7.767.

\section{GLOSSÁRIO}

AGA - Agravo Regimental em Agravo de Instrumento.

Agr. I. - Agravo de Instrumento.

Ap. Civ. - Apelação Cível.

C. Ciṿ. -Câmara Cível.

CNPq- PIBIC - Conselho Nacional de Pesquisa - Programa de Incentivo à Bolsas de Iniciação Científica.

Des. - Desembargador.

Em. Dec. - Embargos de Declaração.

Em. Infr. - Embargos Infringentes.

EDRESp. Embargos de Declaração em Recurso Especial.

i. - julgado.

RE - Recurso Extraordinário. 
Rel-Relator.

RESP - Recurso Especial

REMS - Recurso Especial em Mandado de Segurança.

ROMS - Recurso Ordinário em Mandado de Segurança.

RT-Revista dos Tribunais.

STF-Superior Tribunal Federal.

STJ -Superior Tribunal de Justiça.

RSTJ - Revista do Superior Tribunal de Justiça.

TJRGS - Tribunal de Justiça do Rio Grande do Sul

UFRGS - Universidade Federal do Rio Grande do Sul. 